\title{
Understanding Islamic Bank Selection of Customers: A Field Research from Turkish Participation Banks
}

\author{
Ali Polat ${ }^{1}$, Mehmet Yeşilyaprak ${ }^{2}$ \& Raci Kaya ${ }^{3}$ \\ ${ }^{1}$ College of Business Administration, King Saud University, Riyadh, Saudi Arabia \\ ${ }^{2}$ Head of Analysis of Insurance and Guarantee Department, Turk Eximbank, Istanbul, Turkey \\ ${ }^{3}$ Executive Vice President, Aktif Bank, Istanbul, Turkey \\ Correspondence: Ali Polat, College of Business Administration, King Saud University, Riyadh, 71115, 11587, Saudi \\ Arabia. Tel: 966-11-467-4369. E-mail: apolat@hotmail.com
}

Received: February 19, 2014

Accepted: March 10, $2014 \quad$ Online Published: August 24, 2014

doi:10.5430/ijfr.v5n4p22

URL: http://dx.doi.org/10.5430/ijfr.v5n4p22

\begin{abstract}
Bank customers have a selection behavior in their banking activities. It is important to understand the factors that the customers of Islamic Banks select the banks as their financial services providers. Such understanding has many micro and macro level advantages from policy making to marketing and forecasting.

This paper tries to extract important components in Islamic bank selection of the bank customers in Turkey. Principle Component Analysis (PCA) is used in exploratory data analysis to 341 customer surveys that were obtained from the customers of participation banks in Turkey. We found that three latent variables are important for the Turkish Participation Bank customers in their bank selection. The customers care for i) Islamic Banking ii) Quality Banking and iii) Fast Banking. Our literature review on Islamic bank selection and our results suggest that providing Islamic Banking is a must while alone is not enough criteria for an Islamic Bank to be selected by customers.
\end{abstract}

Keywords: principal component analysis, participation bank, Islamic bank, customer selection, bank

\section{Introduction}

The growth of Islamic banking (IB) all over the world in the last decade is a well-known phenomenon. Its average growth rate per annum outpaces traditional banks. In a recent report Ernst\&Young (2012) indicates that IB grows 50 percent faster than the overall conventional banking sector. IB annual growth rate over 2008-2011 was around 19 percent and it is expected that IB will reach more than 2 trillion dollars by 2014. Ernst\&Young (2013) suggest that IB global cumulative assets including commercial banks are projected to cross 1.7 trillion dollars in 2013, meaning 17.6 percent annual growth in last four years. Such growth includes a slowdown trend caused by some major problems due to economic and political setbacks in some IB markets and due to the fact that many IBs initiated about 18 months ago and still in the phase of consume and investment rather than profit making.

IBs are designed first as to provide "acceptable" financial services to the Muslim community but the current market practices shows us that both Islamic financial services users and providers belong to different belief systems interact with Islamic financial services. The interest on IB from international conventional banks creates a strong competition environment due to non-Islamic rivals in the market. (Haque, Osman, \& Ismail, 2009) From a logical perspective, IBs cannot rely on only "Sharia approval" as there are customers who have no such concerns because they are non-Muslims and again they cannot rely on the same notion due to fierce competition with conventional and Islamic counterparties. IBs should not overemphasize and rely on religious factor as a strategy for more customer attraction. (Haron, Ahmad, \& Planisek, 1994; Saini, Bick, \& Abdulla, 2011) Sharia approval is a prerequisite of IB for caring Muslim customers only while non-Muslims or some other Muslims might even not require it when they choose their banks. Those customers requiring Sharia approval in the activities of IB will probably be not satisfied with only Sharia approval and require some other qualities endogenous in their IB.

Literature review part of our research shows that in addition to religious motivation there are other factors like cost, benefit, service delivery, convenience and friendliness of bank personnel in bank selection of customers. Therefore, bank selection motive of customers is a fundamental issue in both IB and conventional banking activities. 
Bank selection criteria of the customers first discussed within conventional banking context. Satisfaction, loyalty and profitability are related to one another in customer satisfaction. Hallowell (1996) shows by ordinary least square (OLS) regression of cross-sectional US banking data that customer satisfaction and customer retention and customer retention and profitability have relationship. They also found that the role of price satisfaction in forecasting customer loyalty is unclear.

It is important to understand bank selection criteria of customers to shape Islamic financial services production and to have a robust growth strategy in IB. Eriksson (2008) indicates that bank customers and their preferences are the major determinants of the future banking. In that case, it becomes crucial to develop a banking model which has the ability to satisfy critical bank selection factors for the related market segments and customers. (Ta \& Har, 2000) Because of this requirement, Dali, Yousafzai, and Hamid (2013) suggest that a new model for customer satisfaction of IB should be employed. Currently there is no generally accepted model explains the financing selection behavior of IB customers. Generalization of preferences might be problematic for different markets, banks and customer structures for the whole world but it is possible to analyze and find the local behaviors of customers in specific markets.

Our research tries to answer the most important factors in customers' bank selection in IB in Turkey. Turkey is a unique country with its long lasting Islamic legacy and comparatively recent liberal and secular structure with 95 percent Muslim population of 76 million people. Currently, there are four IB operating in Turkey and this research has survey results of the customers from those IB without including any sample from conventional banks in Turkey. Interest free banking in Turkey is called Participation Banking by law due to the participatory nature of these banks.

After the introduction as first section in this paper, the second section gives a literature review on the topic both from conventional and IB sides. The third section indicates the data and methodology while the fourth section discusses the results and findings. The last section concludes the findings.

\section{Literature Review}

Determinants of bank selection criteria in the literature have been studied both from theoretical and practical dimensions. Customer's bank preferences or selection criteria are not only an important choice for IB but also a crucial indicator in conventional banking providers too. As this paper will concentrate on IB selection criteria of the customers more in detail, we provide a brief literature review in Table 1 for conventional banks only. We will discuss IB related literature review in detail. There are some other studies about bank selection that are not mentioned here though Table 1 gives the tendencies of customers in their bank selection criteria. Abduh and Omar (2012) summarized the methods of analysis employed in these kind of research related with customer bank selection. Analysis in literature differentiates extensively from descriptive statistics to advanced econometrics like JJ-co-integration and Autoregressive Distributed Lags (ARDL).

We developed the review part in a way that the conventional research is provided in a table (Table 1) while the more related research, namely IB, is discussed in more details.

Table 1. Bank selection literature in conventional banking

\begin{tabular}{|c|c|c|}
\hline Researcher/s & $\begin{array}{l}\text { Research } \\
\text { Country }\end{array}$ & Important Selection Criteria \\
\hline $\begin{array}{l}\text { (Laroche, Rosenblatt, \& Manning, } \\
\text { 1986) }\end{array}$ & Canada & $\begin{array}{l}\text { Speed of services, competence and } \\
\text { friendliness of bank staff, convenience of } \\
\text { location. }\end{array}$ \\
\hline (Kennington, Hill, \& Rakowska, 1996) & Poland & Reputation, price and service. \\
\hline (Zineldin, 1996) & Sweden & $\begin{array}{l}\text { Friendliness and helpfulness of staff, } \\
\text { accuracy in account/transaction } \\
\text { management, availability of loans and } \\
\text { provision of services }\end{array}$ \\
\hline (Ülengin, 1998) & Turkey & $\begin{array}{l}\text { Extended loyalty programs, the continuous } \\
\text { information flow from the bank, the off-site } \\
\text { ATMs, the maximum five-minutes waiting } \\
\text { time in the branches, a simple application for } \\
\text { all the accounts the bank offers. Delivery } \\
\text { channels, customer relations }\end{array}$ \\
\hline (Owusu-Frimpong, 1999) & Ghana & Low service charges, high interest rates \\
\hline
\end{tabular}




\begin{tabular}{|c|c|c|}
\hline (Ta \& Har, 2000) & Singapore & $\begin{array}{l}\text { High saving deposit interest rates, } \\
\text { convenience, quality of service. }\end{array}$ \\
\hline (Almossawi, 2001) & Bahrain & $\begin{array}{l}\text { Reputation, parking space near the bank, } \\
\text { friendliness of bank personnel, availability } \\
\text { and location of ATM }\end{array}$ \\
\hline (Colgate \& Hedge, 2001) & $\begin{array}{l}\text { Australia\& } \\
\text { New Zealand }\end{array}$ & $\begin{array}{l}\text { Service Failures, pricing problems, denied } \\
\text { services. }\end{array}$ \\
\hline (Devlin, 2002) & The UK & $\begin{array}{l}\text { Price and service quality factors, corporate } \\
\text { brand and relationship factors. }\end{array}$ \\
\hline $\begin{array}{l}\text { (Abou Aish, Ennew, \& McKechnie, } \\
\text { 2003) }\end{array}$ & The UK, Egypt & $\begin{array}{l}\text { Brand, fees, interest rates and credit } \\
\text { availability }\end{array}$ \\
\hline $\begin{array}{l}\text { (Che Aniza binti Che Wel \& Mohd, } \\
\text { 2003) }\end{array}$ & Malaysia & $\begin{array}{l}\text { More personal factors compared to } \\
\text { sociological factors }\end{array}$ \\
\hline (Tank \& Tyler, 2005) & The UK & $\begin{array}{l}\text { Reputation, image, recommendation by } \\
\text { friends and family. }\end{array}$ \\
\hline (Kaynak \& Harcar, 2005) & The USA & Service, image, charges \\
\hline (Blankson, Cheng, \& Spears, 2007) & $\begin{array}{l}\text { The USA, } \\
\text { Taiwan, Ghana }\end{array}$ & $\begin{array}{l}\text { Convenience, competence, recommendation } \\
\text { by peers, free banking }\end{array}$ \\
\hline (Şafakli, 2007) & Northern Cyprus & $\begin{array}{l}\text { Service Quality and Efficiency, Bank Image, } \\
\text { Convenient Location, Parking facilities, } \\
\text { financial factors }\end{array}$ \\
\hline (Kamakodi \& Khan, 2008) & India & $\begin{array}{l}\text { Safety of funds, secured ATMs, ATMs } \\
\text { availability, reputation. }\end{array}$ \\
\hline (Rehman \& Ahmed, 2008) & Pakistan & $\begin{array}{l}\text { Customer service, convenience, online } \\
\text { banking }\end{array}$ \\
\hline (Blankson, Omar, \& Cheng, 2009) & Cross country & $\begin{array}{l}\text { Convenience, } \\
\text { recommetence, }\end{array}$ \\
\hline $\begin{array}{l}\text { (Mylonakis, Malliaris, \& Siomkos, } \\
\text { 2011) }\end{array}$ & Greece & Convenience and quality of service. \\
\hline (Aregbeyen, 2011) & Nigeria & Safety of funds, technology based services \\
\hline $\begin{array}{l}\text { (Katircioglu, Fethi, Unlucan, \& Dalci, } \\
\text { 2011) }\end{array}$ & Northern Cyprus & $\begin{array}{l}\text { Availability and convenient location of } \\
\text { ATM services and speed and quality of } \\
\text { service }\end{array}$ \\
\hline
\end{tabular}

Source: Created from the used literature

The last column of Table 1 shows the important selection criteria of customers in the research countries for conventional banks only. Keeping these criteria in mind, we can now look at the IB literature for customer bank selection. Another point to keep in mind is made by Chong and Liu (2009) that Iran, Pakistan and Sudan have only IB. Therefore, any customer bank selection literature for these countries implies that "Islamic" variable is constant.

N. Ahmad and Haron (2002) analyzed corporate customers perception of IB services and products in Malaysia and found that first selection criterion appears cost/benefit. Only 11 percent of the participants indicate religion as their selection criterion. This is also interesting in terms of the behaviors of corporates and individuals in their selection. Corporate customers in this research appear to be more sensitive to cost/benefit rather than religious motivations.

IB selection criteria develops comparatively recently in literature and especially in some specific countries. Haque et al. (2009) used a logit model in their study of Malaysian customer preferences. Selection of IB has positive relationship with quality and availability of services, social and religious perspective and confidence in bank with customers' perception of IB. Personnel competency and friendliness, strategic location, efficiency of services are the variables provide customer satisfaction for IBs.

Marimuthu, Wai Jing, Phei Gie, Pey Mun, and Yew Ping (2010) looked at IB selection criteria in Malaysia by a non-parametric approach and their result indicate that cost-benefits, service delivery, convenience, friend/relatives have significantly in relationship with the acceptance of IB.

K. Ahmad, Rustam, and Dent (2011) surveyed 300 university students of International Islamic University of 
Malaysia (reflecting some international dimensions) and investigated the factors that determine a customer's bank selection. Convenience, ATMs and their locations, parking space, the attractive location of the banks and its opening hours are all important factors in selection criteria. These criteria show us that although IB is different from conventional banks, the customer choices can create a competitive environment.

Thambiah, Ramanathan, and Mazumder (2012) conducted a survey in Malaysia to analyze the determinants of Islamic retail bank adoption and found that relative advantage, compatibility, promotional efforts, complexity and consumer awareness seems to have significant relationship in adoption of Islamic retail banking services.

Saad (2012) found in the comparative analysis of customer satisfaction in Malaysia that customers are mostly pleased by the quality of services which include competency, friendliness and efficiency of the staff of the both type of banks. The paper also indicates that less satisfied factors for both types of banks are bank physical facilities, parking availability and access to public transportation.

Abduh and Omar (2012) approached IB selection criteria from another perspective and concluded that IBs cannot be too liberal by following all the footprints of conventional banks. By applying analytic hierarchy processes (AHP) to respondents from Malaysia, they indicate that the most important attribute for individuals in Malaysia to patronize an Islamic bank is Sharia-compliance.

Nawi, Yazid, and Mohammed (2013) provided a literature review for IB selection criteria in Malaysia and indicated six main reasons for customers preferring Islamic banking which are i) understanding of IB concept, ii) Sharia'h compliance, iii) religious contradiction, iv) quality and attractiveness of offerings, v) willingness to deal with IBs vi) prospects and potentials of IBs.

Kishada and Wahab (2013) showed through principle component analysis (PCA) applied to a sample of 250 respondents in Malaysia that trust plays an important role in customer loyalty in Islamic Banking.

Edris (1997) analyzed Kuwait in terms of services regarded as important to corporate customers and determinants of bank selection. By applying a segmentation analysis, they determine that size of bank assets, efficiency of staff, help in financial emergencies, bank experience, friendliness of staff, reputation, communication with staff, knowledge about the firms' activities, prompt provision of services and availability of branches abroad are determinants of bank selections. The study also reveals that being Kuwaiti, non-Kuwaiti, and joint business firms can be determinants of bank selection.

Gerrard and Cunningham (1997) studied Singapore and Islamic banking by analyzing approaches of Muslim and non-Muslim customers. Mansour, Abdelhamid, Masood, and Niazi (2010) find in their survey of 156 United Kingdom located respondents that low service charges regardless of the demographic features and the religion of the respondent was the first criterion of the customers' criteria and it is followed by religious orientation.

Khattak and Kashif-Ur-Rehman (2010) confirmed that in Pakistan customers select IBs because of religious motivations. That is followed by speed and efficiency of transaction, trust and working hours. Awan and Bukhari (2011) analyzed customer attitudes towards IB in Pakistan by a sample of 250 respondents and their findings indicate that product features and quality of service shape the selection of IB. Religious belief is found to have lesser importance.

Hedayatnia and Eshghi (2011) applied a factor analysis for Iran and within 38 factors extracted from relevant literature they find that quality of services, new banking methods, innovation and responsiveness of banks, friendliness of staff and confidence in manager, price and cost, staff attitude and convenience of bank location and services are the most important factors in customers' bank selection.

Saini et al. (2011) found for South Africa that Muslims are aware of IBs but comparing to their awareness the rate of use is not high. The factors Muslim customers consider important are efficiency, lower bank charges, the availability of ATMs and extensive branch network.

Okumuş (2005) analyzed customer satisfaction and bank selection criteria for Turkey through a survey. The predominant selection criteria are religious based decisions, staff friendliness, efficiency and speed in completing a transaction and high rate of return. Same research indicates high return expectation as a low factor in customer choices. Karamustafa and Yildirım (2007) found that the factors influence bank selection in a city of Turkey is the credibility of bank, fast service without waiting for long queue and availability of ATMs while the factors causes to change a bank are frequent faulty operations, delay in operations and unsatisfied consumer complaints. Gençtürk, Kalkan, and Oktar (2011) in another local research in Turkey found that increasing customer satisfaction is the most important factor in customer choices. Özsoy, Görmez, and Mekik (2013) in a local sample in Turkey investigated the 
reasons for selecting a participation bank and found that Product/Service quality, image and trust, personnel quality and religious/environmental motivations are found to be principal factors affecting the preference of customers. Kaytanc1, Ergeç, and Toprak (2013) found that most of the customers of IBs in Turkey are satisfied with the products and services.

As a conclusion from literature review that there are many factors influence the choice of the bank of the customers. This paper tries to answer what are the behavioral motives of customers in their selection criteria of participation banks in Turkish Banking System. Usually, religious sensitivity is considered to be the main driver of customer demand in Participation banking and therefore only channel for Muslims in obtaining financial services. With this research, we try to see the most important factors effecting customer choices in addition to this religious sensitivity.

\section{Data and Empirical Methodology}

The study covers four participation banks operating in Turkey. As the study does not concentrate on revealing bank-specific information, we did not indicate the bank names in our research. We distributed our structured survey to the branches of participation banks located in Istanbul and face-to-face surveys are applied. 341 surveys are received and used in our analysis. Table 2 shows the number of samples received from each participation bank customers. Comrey and Lee (1992) recommends N>200 and Tabachnick and Fidell (2007) describe that 300 as a good sample size. We consider our sample size as better than a good sample.

Table 2. Surveys obtained from participation banks

\begin{tabular}{cccccc}
\hline $\begin{array}{c}\text { X Participation } \\
\text { Bank }\end{array}$ & $\begin{array}{c}\text { Y Participation } \\
\text { Bank }\end{array}$ & $\begin{array}{c}\text { Z Participation } \\
\text { Bank }\end{array}$ & $\begin{array}{c}\text { T Participation } \\
\text { Bank }\end{array}$ & Total \\
\hline Sample & 104 & 64 & 72 & 101 & $\mathbf{3 4 1}$ \\
\hline
\end{tabular}

The survey has three sections; first section includes demographic information and second section includes selection reasons of participation and conventional banks as controlling variables. Last section has 23 Likert type questions about service quality and other participation banking related questions. We finalized the scales and survey after two academicians and five bank professionals working in participation banks analyzed the questionnaire.

We confirm the face validity of our research by specialist views and obtain structural validity by Principal Component Analysis (PCA). Dunteman (1989) clarify the procedure and differences between factor analysis (FA) and PCA. Briefly, PCA decompose the data into a set of linear variates while FA derives a mathematical model from the factors that are estimated. However, solutions of FA and PCA differ little from each other. (Guadagnoli \& Velicer, 1988) unless variables are less than 20 and communalities are $<0.4$. (Stevens, 2009)

PCA is an essential step in data analysis and is used to understand the underlying dimensions or relationships in the research. At the cornerstone of factor extraction is the postulate that there exist internal but unobservable attributes. (Tucker \& MacCallum, 1997) EFA transforms the correlations among observed variables into a smaller number of latent factors that carry all the required information about the linear interrelationships among the original variables. Habing (2003) explains that if we have p number of observed variables (the Xi) that have been measured for each of the $\mathrm{n}$ subjects, it can be standardized as

$$
\mathrm{X}_{1}=\mathrm{a}_{11} \mathrm{~F}_{1}+\ldots \mathrm{a}_{1 \mathrm{~m}} \mathrm{~F}_{\mathrm{m}}+\mathrm{e}_{1 \text { to }} \quad \mathrm{X}_{\mathrm{p}}=\mathrm{a}_{\mathrm{p} 1} \mathrm{~F}_{1}+\ldots \mathrm{a}_{\mathrm{pm}} \mathrm{F}_{\mathrm{m}}+\mathrm{e}_{\mathrm{p}}
$$

We can show the same as a matrix

$$
\mathrm{X}_{\mathrm{px} 1}=\mathrm{A}_{\mathrm{pxm}} \mathrm{F}_{\mathrm{mx1}}+\mathrm{e}_{\mathrm{px} 1}
$$

Above matrix is equal to

$$
\Sigma=\mathrm{AA}^{\mathrm{T}}+\operatorname{cov}(\mathrm{e})
$$

Errors are assumed to be independent, $\operatorname{cov}(\mathrm{e})$ should be a pxp diagonal matrix. $\Sigma_{\mathrm{pxp}}$ is the correlation matrix of $\mathrm{X}_{\mathrm{px} 1}$. Therefore,

$$
\operatorname{Var}(\mathrm{Xi})=\sum_{j=1}^{m} a 2_{i j}+\operatorname{Var}\left(\mathrm{e}_{\mathrm{i}}\right)
$$

squared factor loadings ( $\Sigma \mathrm{Xi}$ ) is called as communality. Communality is a measure of the proportion of variance explained by the extracted factors and shows the common variance it has with the other variables. 
In order to continue our analysis it is essential to diagnose the assumptions or requirements of the chosen model. Statistical inference improves if the variables are multivariate normal. We tested our variables for normality and found by Kolmogorov-Smirnov and Shapiro-Wilk test that our data is not normally distributed. Although normality is not a requirement of PCA and EFA, it is important for the supplementary controlling tests to decide whether we will apply parametric or non-parametric methods for the controlling variables. Since our data is not normally distributed, we will only use non-parametric tests in this paper.

Table 3. ANOVA with Tukey's test for nonadditivity

\begin{tabular}{|c|c|c|c|c|c|c|c|}
\hline & & & Sum of Squares & $\mathrm{df}$ & $\begin{array}{c}\text { Mean } \\
\text { Square }\end{array}$ & $\mathrm{F}$ & Sig \\
\hline Betwee & eople & & 2338.395 & 340 & 6.878 & & \\
\hline & Between & Items & 468.770 & 22 & 21.308 & 30.943 & .000 \\
\hline & & Nonadditivity & $28.812^{\mathrm{a}}$ & 1 & 28.812 & 42.071 & .000 \\
\hline Woenlo & Residual & Balance & 5121.984 & 7479 & .685 & & \\
\hline & & Total & 5150.796 & 7480 & .689 & & \\
\hline & Total & & 5619.565 & 7502 & .749 & & \\
\hline Total & & & 7957.960 & 7842 & 1.015 & & \\
\hline
\end{tabular}

Grand Mean $=3.89$

a. Tukey's estimate of power to which observations must be raised to achieve additivity $=2.767$.

We also run Tukey's Test of Additivity if our questions can create a scale altogether. As this test is significant $>.000$ then there is multiplicative interaction. In order to test the means of our questions if they are equal or not we also used Hotelling's T Squared Test and found that our questions have different means. Therefore, we reject the null hypothesis and conclude that there is a significant difference between the mean scores in the sample.

Table 4. Hotelling's T-Squared test

\begin{tabular}{rlrrrr}
\hline Hotelling's T-Squared & F & df1 & \multicolumn{1}{c}{ df2 } & \multicolumn{1}{l}{ Sig } \\
\hline 383.590 & 16.359 & 22 & 319 & .000 \\
\hline
\end{tabular}

In order to check the internal consistency, we used Cronbach's alpha. Cronbach (1951) is the most common measure of scale reliability and considered better than split-half reliability. This alpha is the number of items squared is multiplied by the average covariance between items. Then this value is divided to the sum of all the item variances and item covariances. Cronbach's alpha ranges between 0.00 and 1.00. Although higher values of Alpha are desirable, there is no agreement on critical threshold value. When a set of items has an alpha level of .70 or higher, it is considered acceptably reliable (Urdan, 2010) as a common rule of thumb and above 0.85 as quite good. (Cortina, 1993) In the research, Cronbach's alpha for 23 Questions calculated as 0,903 implies high level of internal consistency. As can be seen in Table 5 , scales reliability is 0.9 , which is highly acceptable.

Table 5. Reliability statistics

\begin{tabular}{ccc}
\hline Scale & $\begin{array}{c}\text { Number of } \\
\text { Questions }\end{array}$ & $\begin{array}{c}\text { Cronbach's } \\
\text { Alpha }\end{array}$ \\
\hline Importance of subjective criteria & 23 & .903 \\
\hline
\end{tabular}

In addition to that, corrected-item total correction range between 0.323 and .636 and deleting any item does not increase alpha level. That is considered positive for the consistency as it can be seen in Appendix 1, Item-Total Statistics. Checking correlation matrix (inter-item correlations) we found several correlations bigger than >.5. Anti-image correlation matrix diagonals are around or bigger than .5

Correlation matrix includes Pearson correlation coefficient between all pairs of questions. Factorability assumption requires that some correlations and degree of collinearity among the variables should be available. If a variable does not correlate with others then it should be ignored. We checked the correlation matrix for the pattern of relationship and we found correlations greater than .3 for many of them and we could not find any greater than .9 which signals for multicollinearity in data. The determinant of the correlation matrix 7.968E-005 (means 0,0007968) is greater than 
the necessary value of 0.00001 .Then, multicollinearity is not a problem for our data. All questions correlate reasonably well with each other and none of the correlation coefficients are excessively large. Therefore, we keep all the questions at this stage in our analysis.

We also checked the measures of sampling adequacy by running The Kaiser-Meyer-Olkin (KMO) Test and Barlett test of Sphericity. KMO test value for our "participation bank service quality and customer preference scale" is calculated as 0,893 . A value higher then 0,50 shows that the data is suitable for factor analysis (Kaiser, 1974). The values closer to 1 indicate that the data set is good for the analysis. Large KMO values indicate correlations between pairs of variables means that these variables can be explained by the other variables meaning that the variables can be grouped into a smaller set of underlying factors

$\mathrm{KMO}$ can be calculated for multiple and individual variables. Anti-Image Matrice in Appendix 2 indicates the KMO for individual variables on the diagonal of the anti-image correlation matrix. The value here should be above 0.5 . Looking at our data, we see that all KMO values are well above 0.5 . The off-diagonal elements in the anti-image correlation matrix reflect a partial correlation between variables and they should be small which are in our matrices.

Table 6. KMO and Bartlett's test

\begin{tabular}{llr}
\hline Kaiser-Meyer-Olkin Measure of Sampling Adequacy. & .893 \\
& Approx. Chi-Square & 3128.533 \\
Bartlett's Test of Sphericity & df & 253 \\
& Sig. & .000 \\
\hline
\end{tabular}

The second test is Barlett test of sphericity where sig value $((p=0,000 / \chi 2=3128,533 ; p<0,01)$ indicates that the correlation between the variables are significant therefore they are the part of the same factor. Barlett test of sphericity compares our correlation matrix to an identity matrix where on the principal diagonal we have 1.0 and zeroes in all other correlations meaning that all variables are perfectly independent from one another. (Field, 2009). If the value of Bartlett is significant that means EFA is appropriate.

There is a discussion in the literature regarding how many factors to keep in analyses. Each factor is associated with a variable with its eigenvalues. Therefore, a cut-off point for selecting factors is required. Cattell (1966) chooses the inflexion of the curve as cut-off point. (Kaiser, 1960) recommend that all factors with eigenvalues greater than 1 should be retained and that is what SPSS and many types of softwares do as default. Jolliffe (1972) finds these criteria as too strict and suggest to keep the factors with eigenvalues more than .7.

In addition to above, statistical packages provide some extraction techniques. The number of factors to retain is a problem and as Ledesma and Valero-Mora (2007) indicates Parallel Analysis, a Monte Carlo simulation technique is the best choice in determining the number of factors to retain in factor analysis. (Horn, 1965; Zwick \& Velicer, 1986)

Table 7. Parallel analysis

(Principal Components \& Random Normal Data Generation)

\begin{tabular}{llll}
\hline Root & Raw Data & Means & Percentile \\
\hline $\mathbf{1 . 0 0 0 0 0 0}$ & $\mathbf{7 . 4 6 8 4 6 8}$ & $\mathbf{1 . 4 9 7 0 4 1}$ & $\mathbf{1 . 5 7 3 5 1 5}$ \\
$\mathbf{2 . 0 0 0 0 0 0}$ & $\mathbf{2 . 4 4 6 8 1 6}$ & $\mathbf{1 . 4 1 7 0 4 6}$ & $\mathbf{1 . 4 7 6 4 4 6}$ \\
$\mathbf{3 . 0 0 0 0 0 0}$ & $\mathbf{1 . 4 5 4 5 7 2}$ & $\mathbf{1 . 3 5 3 4 1 8}$ & $\mathbf{1 . 4 0 1 4 2 7}$ \\
4.000000 & 1.125096 & 1.299621 & 1.343071 \\
5.000000 & 1.025036 & 1.250930 & 1.291758 \\
6.000000 & .941572 & 1.206184 & 1.242280 \\
7.000000 & .875816 & 1.164659 & 1.199589 \\
8.000000 & .755897 & 1.125492 & 1.161092 \\
9.000000 & .710382 & 1.086982 & 1.119080 \\
10.000000 & .652582 & 1.049441 & 1.081357 \\
11.000000 & .617595 & 1.013676 & 1.045628 \\
12.000000 & .611790 & .980776 & 1.011338 \\
13.000000 & .538807 & .947161 & .976520
\end{tabular}




\begin{tabular}{lccc}
14.000000 & .506362 & .912382 & .940390 \\
15.000000 & .465648 & .880249 & .909948 \\
16.000000 & .455725 & .847357 & .875666 \\
17.000000 & .417233 & .814602 & .843353 \\
18.000000 & .409452 & .782054 & .811266 \\
19.000000 & .380081 & .748735 & .780221 \\
20.000000 & .349484 & .714998 & .745642 \\
21.000000 & .296224 & .678303 & .710951 \\
22.000000 & .261033 & .638644 & .676080 \\
23.000000 & .234331 & .590247 & .632122 \\
\hline Ncases & 341 & & \\
Nvars & 23 & \\
Ndatsets & 1000 & \\
Percent & 95 & \\
Raw Data Eigenvalues, \& Mean \& Percentile \\
Random Data Eigenvalues \\
\hline
\end{tabular}

As O'connor (2000) suggested we retained the factors until the value where the eigenvalue from the actual data is greater than the eigenvalue from the random data. To determine the statistically significant eigenvalues we employed a parallel analysis for normally distributed random data for specified data sets. Table7 shows that the third factors eigenvalue is 1.45 and the means obtained from Monte Carlo simulation is 1.35 and 95th percentile is 1.40. (meaning $\mathrm{p}<0.05$ ). The fourth eigenvalue is lower than benchmark eigenvalue of 1.34 and larger than the estimated correlation matrix eigenvalue, then the other factors from 4 to 23 will be ignored.

\section{Empirical Results}

\subsection{Principal Component Analysis}

Depending on the parallel analysis (Monte Carlo simulation), we decided to have 3 factors and therefore we had fixed number of extraction for our analysis. In any case eigen values of the factors are higher than 1 and factor loads are above 0,40 . The scale before loading has 23 variables and by removing 9 variables the scale decreased to 14 . These 14 variables load on 3 factors which explain $\% 58.76$ of the total variance.

We looked the communalities and after the extraction, the average value is 0.58 . The scree plot is also indicative regarding the 3 factor selection through Monte Carlo Simulation. (Appendix 3 and 4). We also looked the reproduced correlations that stem from the model rather than the observed data and give us chance to look at the residuals and compare observed data with the model. As a general rule, if residuals with absolute value greater than 0.05 is more than 50 percent then there should be a concern (Field, 2009). In our data, that was 42 percent. Therefore, the model is a fit of the data although there are rooms for improvement.

Table 8. Total variance explained

\begin{tabular}{lrrrrrr}
\hline $\begin{array}{l}\text { Componen } \\
\mathrm{t}\end{array}$ & \multicolumn{3}{c}{ Initial Eigenvalues } & \multicolumn{3}{c}{$\begin{array}{c}\text { Extraction Sums of Squared } \\
\text { Loadings }\end{array}$} \\
\cline { 2 - 7 } & Total & $\begin{array}{c}\text { \% of } \\
\text { Variance }\end{array}$ & $\begin{array}{c}\text { Cumulative } \\
\text { \% }\end{array}$ & Total & $\begin{array}{c}\text { \% of } \\
\text { Variance }\end{array}$ & $\begin{array}{c}\text { Cumulative } \\
\%\end{array}$ \\
\hline 1 & 4.737 & 33.835 & 33.835 & 4.737 & 33.835 & 33.835 \\
2 & 2.158 & 15.412 & 49.246 & 2.158 & 15.412 & 49.246 \\
3 & 1.332 & 9.516 & 58.762 & 1.332 & 9.516 & 58.762 \\
4 & .861 & 6.148 & 64.910 & & & \\
\hline
\end{tabular}

Extraction Method: Principal Component Analysis.

Note: Factors from 5 to 14 are removed

We can conclude that our model that has three components can explain 60 percent of customer's bank choices. By looking at the Pattern Matrix we can see the related items that they are correlated. 
Table 9. Pattern matrix

\begin{tabular}{|c|c|c|c|c|}
\hline & \multicolumn{3}{|c|}{ Component } & \multirow[b]{2}{*}{ Reliability } \\
\hline & 1 & 2 & 3 & \\
\hline 1. Efficient and fast counter services are given & & & .910 & 0,832 \\
\hline 2. Speed and efficiency of the transactions are satisfactory & & & .917 & \\
\hline 8. Providing interest free loans is enough & & .724 & & \\
\hline 9. Other interest free products and services are available & & .758 & & \\
\hline 10. Compliance to Interest free principles & & .865 & & 0,822 \\
\hline 11. Interest free investment products are available & & .787 & & \\
\hline 12. No interest in transactions & & .691 & & \\
\hline 5. Financial advising is available & .765 & & & \\
\hline 6. Document process is fast & .642 & & & \\
\hline 13. An extensive electronic communication network & .751 & & & \\
\hline 14. Robust international network & .781 & & & 0,825 \\
\hline 15. Enough time is spend for transactions & .687 & & & \\
\hline 17. Competitive products are present & .585 & & & \\
\hline 21. Bank size and capital is satisfactory & .636 & & & \\
\hline
\end{tabular}

Above factor loadings are created by PCA extraction through Promax with Kaiser Normalization. The results show us that the factors that are important in bank selection of customers are i) Quality Banking, ii) Islamic Banking iii) Fast Banking. Each factor has a good reliability alpha level.

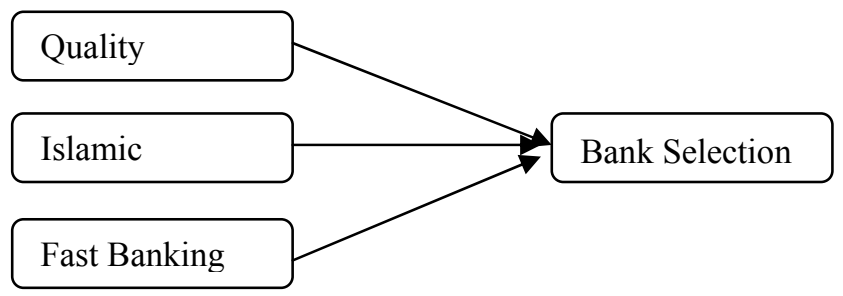

We can say that Turkish participation bank customers require high quality banking services in interest free environment in a fast manner. When we look at the literature review there are many overlapping findings with the already existing findings.

\subsection{Descriptive and Additional Statistics}

Table 10 indicates the demographic statistics. As we indicated above, our sample is not normally distributed and the test we are going to apply here will be non-parametric tests as parametric tests require normal distribution assumption. We have almost 80 percent of respondents male and 20 percent female. Married respondents are 70 percent of our sample. As a general tendency we can say that they are young and middle age which also reflects the nature of Turkish population. College graduates and high school graduates are 45 percent and 33 percent respectively. The tails have surveyors who are 9.7 percent elementary school graduates and 11.1 percent Master-PhD level graduates. 
Table 10. Demographic descriptive statistics

\begin{tabular}{lrrlrr}
\hline Variable & Frequency & $\mathbf{\%}$ & Variable & Frequency & \multicolumn{1}{c}{} \\
\hline Gender & & & Marital Status & & \\
\hline Male & 272 & 79.8 & Married & 237 & 69.5 \\
\hline Female & 69 & 20.2 & Single & 104 & 30.5 \\
\hline Age & & & Education & & \\
\hline $18-29$ & 114 & 33.4 & Elementary & 33 & 9.7 \\
\hline $30-39$ & 122 & 35.8 & High School & 114 & 33.4 \\
\hline $40-49$ & 73 & 21.4 & College & 156 & 45.7 \\
\hline $50-$ & 32 & 9.4 & Master-PhD & 38 & 11.1 \\
\hline Profession & & & & 191 & 56.0 \\
\hline Firm Owner & 67 & 19.6 & Staff & 28 & 8.2 \\
\hline Manager & 55 & 16.1 & Other & & \\
\hline
\end{tabular}

By analyzing means and variances of some questions, we found that IB reaches their customers through Friend, Bank Personnel and Media. Internet and Family seems less effective in choosing a bank. The reason for choosing an IB appears from the mean analysis that Interest sensitivity of the customers very clearly outpaces the others, i.e. cheap products and location. Again, when we asked them what is understood from "appraising banking services" the highest proxy appears service quality and profit distribution. It worths mentioning that the IB customers working with those banks show a positive trend for the future. Table 11 shows that in last 6 years IB had more than 60 percent of their customers.

Table 11. Customer working duration with Islamic bank

\begin{tabular}{llrr}
\hline & & Frequency & Percent \\
\hline & less than a year & 49 & 14.4 \\
& $1-5$ years & 162 & 47.5 \\
For how long do you work with Participation banks? & 6-10 years & 77 & 22.6 \\
& more than 10 years & 53 & 15.5 \\
& Total & 341 & 100.0 \\
\hline
\end{tabular}

We also run several tests to have further understanding of the market regarding if there is any significance for age, education, status, income, cost, knowledge etc. In Table 12 there appear the Kruskal Wallis Test results for some grouping variables and the factors affects customer choices that we have found through EFA. The significant results of the Kruskal Wallis tests are indicated as bold and with stars. For the values without star and $p$ value more than 0.05 we reject the mean ranks of grouping variables are significantly different among our three factors. The hypothesis for the test is as follow:

H0: Age/Sex/Marital Status/Education/Profession groups have the same median.

H1: Age/Sex/Marital Status/Education/Profession groups does not have the same median.

Depending on age group fast banking is important and there is a significant difference between different age groups. Sex and marital status are not significantly affecting any of the important factors. We find that education levels differ for the quality banking and fast banking factors while profession group differs only in fast banking. 
Table 12. Kruskal Wallis tests

\begin{tabular}{llrrr}
\hline Grouping Var. & & Quality Banking & Interest Free Banking & Fast Banking \\
\hline \multirow{2}{*}{ Age } & Chi-Square & 4.869 & 2.405 & 14.334 \\
& Sig. & .182 & .493 & $\mathbf{. 0 0 2 *}$ \\
\hline \multirow{2}{*}{ Sex } & Chi-Square & .672 & .805 & .168 \\
& Sig. & .412 & .370 & .682 \\
\hline \multirow{2}{*}{ Marital Status } & Chi-Square & .002 & 1.759 & 1.322 \\
& Sig. & .962 & .185 & .250 \\
\hline \multirow{2}{*}{ Pducation } & Chi-Square & 9.251 & 4.689 & 11.315 \\
& Sig. & $\mathbf{. 0 2 6 *}$ & .196 & $\mathbf{. 0 1 0 *}$ \\
\hline Incofession & Chi-Square & 7.048 & .990 & 13.392 \\
& Sig. & .070 & .804 & $\mathbf{. 0 0 4 *}$ \\
& Chi-Square & 1.418 & 10.998 & 3.954 \\
& Sig. & .701 & $\mathbf{. 0 1 2 *}$ & .266 \\
\hline
\end{tabular}

Interest free banking is not significantly different in any grouping variable. That makes sense as the interest free banking factor is such an important factor that can create a positive bias in favor of IB that the customers are not elastic in. In our sample, 35 percent of the respondents only work with IB and 55 percent of the respondents declared that even if IB are more costly, they would prefer IB.

We also run several Mann-Whitney Tests some of which are at Appendix 5 to look at differences in the ranked positions of scores between controlling variables and three different components. Having accounts in both IB and conventional banks and having worked with commercial banks before do not effect ranking of the components. All groups in the related loadings do not differentiate if IBs are more costly than conventional banks although there are differences in customers regarding their willingness of working with IB even if they are costly or not. Fast and Quality banking means are significantly different from the means of Interest Free Banking. IB customers, whatever component they are interested in, are different from each other.

\section{Conclusion}

This study attempts to determine the bank selection criteria of participation bank customers. It appears that the bank customers will select an Islamic bank depending on their high quality bank services and fast banking in terms of "conventional" need of a customer. The third latent variable is the Islamic Banking. Turkey is a very competitive and developed market in terms of banking services. The modern structure of business and business environment require banks to provide high quality product but also in a fast manner. Briefly, we can say that the two latent variables are the selection criteria of the market conditions. However, the other selection criteria, Islamic banking services, are the core and basic requirement of an Islamic Bank.

In our scale, we had five questions for Islamic banking: providing interest free loans, compliance to interest free principles, providing interest free investment products, providing other interest free products and services and in general having no interest in transactional level. We understand that these customers with sensitivity to Islamic rules will be satisfied and select a bank if they have this "Islamic" dimension. The other two dimensions of high quality and fast banking is the nature of the market and can be explained due to the fact that Turkish banking system use high technology in international standards. GDP growth and young population of the countries in the last decade requires the services to be faster than ever. Therefore, the efficiency and customer acceptance of an IB in Turkey will be higher if they provide the highest standard of Islamic Banking satisfying customer needs and by providing high quality and fast banking.

\section{Acknowledgement}

The Researchers would like to thank the Deanship of Scientific Research at King Saud University, represented by the research center at CBA, for supporting this research financially. 


\section{References}

Abduh, M., \& Omar, M. A. (2012). Islamic-Bank Selection Criteria in Malaysia: An AHP Approach. Business Intelligence Journal, 5(2), 271-282.

Abou Aish, E. M., Ennew, C. T., \& McKechnie, S. A. (2003). A cross-cultural perspective on the role of branding in financial services: The small business market. Journal of Marketing Management, 19(9-10), 1021-1042. http://dx.doi.org/10.1080/0267257X.2003.9728249

Ahmad, K., Rustam, G. A., \& Dent, M. M. (2011). Brand preference in Islamic banking. Journal of Islamic Marketing, 2(1), 74-82. http://10.1108/17590831111115259

Ahmad, N., \& Haron, S. (2002). Perceptions of Malaysian corporate customers towards Islamic banking products and services. International Journal of Islamic Financial Services, 3(4), 13-29.

Almossawi, M. (2001). Bank selection criteria employed by college students in Bahrain: an empirical analysis. International Journal of Bank Marketing, 19(3), 115-125. http://dx.doi.org/10.1108/02652320110388540

Aregbeyen, O. (2011). The Determinants of Bank Selection Choices by Customers: Recent and Extensive Evidence from Nigeria. Int. J. Bus. Soc. Sci, 2(22), 276-288.

Awan, H. M., \& Bukhari, K. S. (2011). Customer's criteria for selecting an Islamic bank: evidence from Pakistan. Journal of Islamic Marketing, 2(1), 14-27. http://10.1108/17590831111115213

Blankson, C., Cheng, J. M.-S., \& Spears, N. (2007). Determinants of banks selection in USA, Taiwan and Ghana. International Journal of Bank Marketing, 25(7), 469-489. http://dx.doi.org/10.1108/02652320710832621

Blankson, C., Omar, O. E., \& Cheng, J. M. S. (2009). Retail bank selection in developed and developing countries: A cross-national study of students' bank-selection criteria. Thunderbird International Business Review, 51(2), 183-198. http://dx.doi.org/10.1002/tie.20257

Cattell, R. B. (1966). The scree test for the number of factors. Multivariate behavioral research, 1(2), $245-276$. http://dx.doi.org/10.1207/s15327906mbr0102_10

Che Aniza binti Che Wel, S., \& Mohd, N. (2003). The influences of personal and sociological factors on consumer bank selection decision in Malaysia. Journal of American Academy of Business, Cambridge, 3, 399.

Chong, B. S., \& Liu, M.-H. (2009). Islamic banking: interest-free or interest-based? Pacific-Basin Finance Journal, 17(1), 125-144. http://dx.doi.org/10.1016/j.pacfin.2007.12.003

Colgate, M., \& Hedge, R. (2001). An investigation into the switching process in retail banking services. International Journal of Bank Marketing, 19(5), 201-212.

Comrey, A. L., \& Lee, H. B. (1992). A first course in factor analysis. Routledge.

Cortina, J. M. (1993). What is coefficient alpha? An examination of theory and applications. Journal of applied psychology, 78(1), 98. http://dx.doi.org/10.1037/0021-9010.78.1.98

Cronbach, L. J. (1951). Coefficient alpha and the internal structure of tests. Psychometrika, 16(3), $297-334$. http://dx.doi.org/10.1007/BF02310555

Dali, N., Yousafzai, S., \& Hamid, H. (2013). The Development Of Islamic Banking \& Finance. Underpinning Theory Affecting Islamic Banking Consumers Post Purchase Behavior. 2nd International On ASEAN Economics Development, Thailand, 1-15.

Devlin, J. F. (2002). Customer knowledge and choice criteria in retail banking. Journal of Strategic Marketing, 10(4), 273-290. http://dx.doi.org/10.1080/0965254022000014541

Dunteman, G. H. (1989). Principal components analysis. Sage.

Edris, T. A. (1997). Services considered important to business customers and determinants of bank selection in Kuwait: a segmentation analysis. International Journal of Bank Marketing, 15(4), 126-133. http://dx.doi.org/10.1108/02652329710189393

Eriksson, K. (2008). The future of retail banking. International Journal of Bank Marketing, 26(1).

Ernst\&Young. (2012). The World Islamic Banking Competitiveness Report 2013-2013: Growing Beyond: DNA of Successful Transformation. In S. Qureshi (Ed.), (pp. 108). Dubai: Ernst\&Young. 
Ernst\&Young. (2013). The World Islamic Banking Competitiveness Report 2013 2014: The transition begins. In A. Nazim (Ed.). Dubai: Ernst\&Young.

Field, A. (2009). Discovering statistics using SPSS. Sage publications.

Gençtürk, M., Kalkan, A., \& Oktar, F. (2011). The Factors Influencing Customer Satisfaction in Retail Banking: An Application in Burdur and Isparta. Suleyman Demirel University The Journal of Faculty of Economics and Administrative Sciences, 16(2), 59-77.

Gerrard, P., \& Cunningham, J. B. (1997). Islamic banking: a study in Singapore. International Journal of Bank Marketing, 15(6), 204-216. http://dx.doi.org/10.1108/02652329710184433

Guadagnoli, E., \& Velicer, W. F. (1988). Relation to sample size to the stability of component patterns. Psychological bulletin, 103(2), 265. http://dx.doi.org/10.1037/0033-2909.103.2.265

Habing, B. (2003). Exploratory factor analysis. Habing. courses, 20-30. Retrieved from http: www.stat.sc.edu

Hallowell, R. (1996). The relationships of customer satisfaction, customer loyalty, and profitability: an empirical study. International journal of service industry management, 7(4), 27-42. http://dx.doi.org/10.1108/09564239610129931

Haque, A., Osman, J., \& Ismail, A. Z. (2009). Factor influences selection of Islamic banking: a study on Malaysian customer preferences. American Journal of Applied Sciences, 6(5), 922. http://dx.doi.org/10.3844/ajassp.2009.922.928

Haron, S., Ahmad, N., \& Planisek, S. L. (1994). Bank patronage factors of Muslim and non-Muslim customers. International Journal of Bank Marketing, 12(1), 32-40. http://dx.doi.org/10.1108/02652329410049599

Hedayatnia, A., \& Eshghi, K. (2011). Bank selection criteria in the Iranian retail banking industry. International Journal of Business and Management, 6(12), 222. http://dx.doi.org/10.5539/ijbm.v6n12p222

Horn, J. L. (1965). A rationale and test for the number of factors in factor analysis. Psychometrika, 30(2), 179-185. http://dx.doi.org/10.1007/BF02289447

Jolliffe, I. (1972). Discarding variables in a principal component analysis. I: Artificial data. Applied Statistics, 160-173. http://dx.doi.org/10.2307/2346488

Kaiser, H. F. (1960). The application of electronic computers to factor analysis. Educational and psychological measurement. http://dx.doi.org/10.1177/001316446002000116

Kaiser, H. F. (1974). An index of factorial simplicity. Psychometrika, 39(1), 31-36. http://dx.doi.org/10.1007/BF02291575

Kamakodi, N., \& Khan, B. A. (2008). An insight into factors influencing bank selection decisions of Indian customers. Asia Pacific Business Review, 4(1), 17-26. http://dx.doi.org/10.1177/097324700800400102

Karamustafa, K., \& Yıldırım, M. (2007). Tüketicilerin Bireysel Banka Tercihine İlişkin Kayseri İlinde Yapılan Bir Araştırma. AIBÜ-IIBBF Ekonomik ve Sosyal Araştırmalar Dergisi.

Katircioglu, S., Fethi, S., Unlucan, D., \& Dalci, I. (2011). Bank selection factors in the banking industry: an empirical investigation from potential customers in Northern Cyprus. Acta Oeconomica, 61(1), 77-89. http://dx.doi.org/10.1556/AOecon.61.2011.1.5

Kaynak, E., \& Harcar, T. D. (2005). American consumers' attitudes towards commercial banks: A comparison of local and national bank customers by use of geodemographic segmentation. International Journal of Bank Marketing, 23(1), 73-89. http://dx.doi.org/10.1108/02652320510577375

Kaytanc1, G., Ergeç, H. E., \& Toprak, M. (2013, 17-18 September). Satisfaction of Islamic Banks' Costumers: The Case of Turkey. Paper presented at the International Conference on Eurasian Economies, St. Petersburg, Russia.

Kennington, C., Hill, J., \& Rakowska, A. (1996). Consumer selection criteria for banks in Poland. International Journal of Bank Marketing, 14(4), 12-21. http://dx.doi.org/10.1108/02652329610119283

Khattak, N. A., \& Kashif-Ur-Rehman. (2010). Customer satisfaction and awareness of Islamic banking system in Pakistan. African Journal of Business Management, 4(5), 662-671.

Kishada, Z. M. E., \& Wahab, N. A. (2013). Factors Affecting Customer Loyalty in Islamic Banking: Evidence from Malaysian Banks. International Journal of Business and Social Science, 4(7), 264-273. 
Laroche, M., Rosenblatt, J. A., \& Manning, T. (1986). Services used and factors considered important in selecting a bank: an investigation across diverse demographic segments. International Journal of Bank Marketing, 4(1), 35-55. http://dx.doi.org/10.1108/eb010771

Ledesma, R. D., \& Valero-Mora, P. (2007). Determining the Number of Factors to Retain in EFA: an easy-to-use computer program for carrying out Parallel Analysis. Practical Assessment, Research \& Evaluation, 12(2), $1-11$.

Mansour, W., Abdelhamid, M. B., Masood, O., \& Niazi, G. (2010). Islamic banking and customers' preferences: the case of the UK. Qualitative Research in Financial Markets, 2(3), 185-199. http://10.1108/17554171011091746

Marimuthu, M., Wai Jing, C., Phei Gie, L., Pey Mun, L., \& Yew Ping, T. (2010). Islamic Banking: Selection Criteria and Implications. Global Journal of Human-Social Science Research, 10(4).

Mylonakis, J., Malliaris, P. G., \& Siomkos, G. J. (2011). Marketing-driven factors influencing savers in the Hellenic bank market. Journal of Applied Business Research (JABR), 14(2), 109-116.

Nawi, F. A. M., Yazid, A. S., \& Mohammed, M. O. (2013). A Critical Literature Review for Islamic Banks Selection Criteria in Malaysia. International Business Research, 6(6), 143. http://dx.doi.org/10.5539/ibr.v6n6p143

O'connor, B. P. (2000). SPSS and SAS programs for determining the number of components using parallel analysis and Velicer's MAP test. Behavior research methods, instruments, \& computers, 32(3), 396-402.

Okumuş, H. Ş. (2005). Interest-free banking in Turkey: a study of customer satisfaction and bank selection criteria. Journal of Economic Cooperation, 26(4), 51-86.

Owusu-Frimpong, N. (1999). Patronage behaviour of Ghanaian bank customers. International Journal of Bank Marketing, 17(7), 335-342. http://dx.doi.org/10.1108/02652329910305698

Özsoy, İ., Görmez, B., \& Mekik, S. (2013). Reasons for Preference of Participatory Banks in Turkey: An Empirical Investigation. Yönetim ve Ekonomi, 20(1).

Rehman, H. U., \& Ahmed, S. (2008). An empirical analysis of the determinants of bank selection in Pakistan: a customer view. Pakistan Economic and Social Review, 46(2), 147-160.

Saad, N. M. (2012). Comparative Analysis of Customer Satisfaction on Islamic and Conventional Banks in Malaysia. Asian Social Science, 8(1), 73. http://dx.doi.org/10.5539/ass.v8n1p73

Şafakli, O. V. (2007). A research on the basic motivational factors in consumer bank selection: evidence from Northern Cyprus. Banks and Banks System, 2(4), 93-100.

Saini, Y., Bick, G., \& Abdulla, L. (2011). Consumer awareness and usage of islamic banking products in South Africa. South African Journal of Economic and Management Sciences, 14(3), 298-313.

Stevens, J. P. (2009). Applied multivariate statistics for the social sciences. Taylor \& Francis.

Ta, H. P., \& Har, K. Y. (2000). A study of bank selection decisions in Singapore using the analytical hierarchy process. International Journal of Bank Marketing, 18(4), 170-180. http://dx.doi.org/10.1108/02652320010349058

Tabachnick, B. G., \& Fidell, L. S. (2007). Using multivariate statistics.

Tank, J., \& Tyler, K. (2005). UK student banking revisited: influences and the decision-making process. Journal of financial services marketing, 10(2), 152-164. http://dx.doi.org/10.1057/palgrave.fsm.4770182

Thambiah, S., Ramanathan, S., \& Mazumder, M. N. H. (2012). The Determinants Of Islamic Retail Banking Adoption In Malaysia. International Business \& Economics Research Journal (IBER), 11(4), 437-442.

Tucker, L. R., \& MacCallum, R. C. (1997). Exploratory factor analysis. Unpublished manuscript, Ohio State University, Columbus.

Ülengin, B. (1998). Using hierarchical information integration to examine customer preferences in banking. International Journal of Bank Marketing, 16(5), 202-210. http://dx.doi.org/10.1108/02652329810228217

Urdan, T. C. (2010). Statistics in Plain English. New York: Routledge.

Zineldin, M. (1996). Bank strategic positioning and some determinants of bank selection. International Journal of Bank Marketing, 14(6), 12-22. http://dx.doi.org/10.1108/02652329610130136 
Zwick, W. R., \& Velicer, W. F. (1986). Comparison of five rules for determining the number of components to retain. Psychological bulletin, 99(3), 432. http://dx.doi.org/10.1037//0033-2909.99.3.432

\section{Appendix}

Appendix 1. Item-total statistics

\begin{tabular}{|c|c|c|c|c|c|}
\hline & $\begin{array}{c}\text { Scale } \\
\text { Mean if } \\
\text { Item } \\
\text { Deleted } \\
\end{array}$ & $\begin{array}{c}\text { Scale } \\
\text { Variance if } \\
\text { Item } \\
\text { Deleted } \\
\end{array}$ & $\begin{array}{c}\text { Corrected } \\
\text { Item-Total } \\
\text { Correlation }\end{array}$ & $\begin{array}{c}\text { Squared } \\
\text { Multiple } \\
\text { Correlation }\end{array}$ & $\begin{array}{c}\text { Cronbach's } \\
\text { Alpha if Item } \\
\text { Deleted }\end{array}$ \\
\hline $\begin{array}{l}\text { 1.Efficient and fast counter } \\
\text { services are given }\end{array}$ & 85.61 & 144.975 & 0.492 & 0.576 & 0.896 \\
\hline $\begin{array}{l}\text { 2.Speed and efficiency of the } \\
\text { transactions are satisfactory }\end{array}$ & 85.69 & 145.304 & 0.504 & 0.599 & 0.896 \\
\hline $\begin{array}{l}\text { 3.Convenience of branches are } \\
\text { satisfactory }\end{array}$ & 85.49 & 149.615 & 0.323 & 0.237 & 0.900 \\
\hline $\begin{array}{l}\text { 4.Experienced management is } \\
\text { available }\end{array}$ & 85.54 & 145.855 & 0.574 & 0.442 & 0.894 \\
\hline 5.Financial advising is available & 85.99 & 145.471 & 0.433 & 0.395 & 0.898 \\
\hline 6.Document process is fast & 85.85 & 144.22 & 0.526 & 0.454 & 0.895 \\
\hline $\begin{array}{l}\text { 7.The personnel is knowledgeable } \\
\text { regarding customer's requests }\end{array}$ & 85.39 & 147.838 & 0.527 & 0.362 & 0.896 \\
\hline $\begin{array}{l}\text { 8.Providing interest free loans is } \\
\text { enough }\end{array}$ & 85.49 & 148.71 & 0.352 & 0.367 & 0.899 \\
\hline $\begin{array}{l}\text { 9.Other interest free products and } \\
\text { services are available }\end{array}$ & 85.48 & 145.88 & 0.514 & 0.522 & 0.896 \\
\hline $\begin{array}{l}\text { 10.Compliance to Interest free } \\
\text { principles }\end{array}$ & 85.28 & 147.988 & 0.474 & 0.578 & 0.897 \\
\hline $\begin{array}{l}\text { 11.Interest free investment } \\
\text { products are available }\end{array}$ & 85.45 & 146.484 & 0.486 & 0.49 & 0.896 \\
\hline 12.No interest in transactions & 85.29 & 147.013 & 0.49 & 0.5 & 0.896 \\
\hline $\begin{array}{l}\text { 13.An extensive electronic } \\
\text { communication network }\end{array}$ & 85.98 & 142.32 & 0.589 & 0.508 & 0.894 \\
\hline 14. Robust international network & 86.08 & 143.234 & 0.516 & 0.452 & 0.896 \\
\hline $\begin{array}{l}\text { 15. Enough time is spend for } \\
\text { transactions }\end{array}$ & 85.65 & 144.865 & 0.553 & 0.439 & 0.895 \\
\hline $\begin{array}{l}16 . \text { Branch convenience is } \\
\text { satisfactory }\end{array}$ & 85.93 & 143.122 & 0.459 & 0.413 & 0.898 \\
\hline $\begin{array}{l}\text { 17. Competitive products are } \\
\text { present }\end{array}$ & 85.99 & 141.685 & 0.598 & 0.471 & 0.893 \\
\hline $\begin{array}{l}\text { 18. The same service level is } \\
\text { provided in all branches }\end{array}$ & 85.84 & 145.82 & 0.44 & 0.299 & 0.897 \\
\hline 19. Bank secrecy is important & 85.34 & 145.312 & 0.593 & 0.473 & 0.894 \\
\hline $\begin{array}{l}20 . \text { There is a trust to bank } \\
\text { management }\end{array}$ & 85.3 & 145.475 & 0.636 & 0.522 & 0.893 \\
\hline $\begin{array}{l}\text { 21. Bank size and capital is } \\
\text { satisfactory }\end{array}$ & 85.58 & 143.603 & 0.554 & 0.429 & 0.895 \\
\hline 22. Low transaction fees & 85.65 & 144.723 & 0.467 & 0.364 & 0.897 \\
\hline 23. Average stable return & 85.59 & 144.413 & 0.598 & 0.45 & 0.894 \\
\hline
\end{tabular}

\begin{tabular}{|c|c|}
\hline $\mathrm{N}=341$ & $(\alpha)=0,900$ \\
\hline
\end{tabular}

* item deleted 
Appendix 2. Anti-image matrices (Item Level KMO’s)

\begin{tabular}{|c|c|c|c|c|c|c|c|c|c|c|c|c|c|c|c|c|c|c|c|c|c|c|c|}
\hline $\begin{array}{l}\text { 1.Efficient and fast counter } \\
\text { services }\end{array}$ & $.807^{\mathrm{a}}$ & & & & & & & & & & & & & & & & & & & & & & \\
\hline $\begin{array}{l}\text { 2.Speed and efficiency of } \\
\text { transact }\end{array}$ & .613 & $.805^{2}$ & & & & & & & & & & & & & & & & & & & & & \\
\hline 3. Comfort of branches &. .141 & .072 & $.861^{a}$ & & & & & & & & & & & & & & & & & & & & \\
\hline 4.Experienced management & -.163 &. .043 & -.110 & $.917^{a}$ & & & & & & & & & & & & & & & & & & & \\
\hline 5. Financial advising & .026 & .084 & -.131 & -.069 & $.876^{1}$ & & & & & & & & & & & & & & & & & & \\
\hline 6Fast document processing & .060 & .055 & .015 & -.172 & .330 & $.881^{2}$ & & & & & & & & & & & & & & & & & \\
\hline $\begin{array}{l}\text { 7.Knowledgeable } \\
\text { personnel }\end{array}$ & .089 & .069 & .049 & -.134 & -.113 & -.146 & $.938^{a}$ & & & & & & & & & & & & & & & & \\
\hline SInterest free loans & .052 & .021 & .078 & -.094 & .042 & .016 & -.109 & $.892^{2}$ & & & & & & & & & & & & & & & \\
\hline $\begin{array}{l}\text { 9. Other interest free } \\
\text { products\&services }\end{array}$ & .039 & -.032 & -.004 & .138 & .026 & .062 & -.094 & -.227 & $.883^{2}$ & & & & & & & & & & & & & & \\
\hline $\begin{array}{l}\text { 10. Compliance to Interest } \\
\text { free princ. }\end{array}$ & .002 & .044 & .082 & -.040 & -.034 & .007 & .013 &. .080 & -.318 & $.853^{a}$ & & & & & & & & & & & & & \\
\hline $\begin{array}{l}\text { 11. Interest free investment } \\
\text { products }\end{array}$ & .006 & -.051 & .030 & -.008 & .035 & .053 & .024 & -.135 & -.276 & -.220 & $.916^{2}$ & & & & & & & & & & & & \\
\hline $\begin{array}{l}\text { 12. No interest in } \\
\text { transactions }\end{array}$ & .085 & -.066 & .062 & -.068 & .004 & .073 & -.136 & -.013 & .067 & -.422 &. .047 & $.877^{1}$ & & & & & & & & & & & \\
\hline $\begin{array}{l}\text { 13.Extensive elect. comm. } \\
\text { network }\end{array}$ & .071 & -.133 & .023 & -.077 & -.102 & .057 & .055 & .112 & -.019 & .069 & .086 & -.100 & $916^{a}$ & & & & & & & & & & \\
\hline 14. Robust int. network &. .014 & .020 & .005 & .022 & -.151 & .073 & .076 & .059 & -.113 & .119 & .030 & .013 & -.261 & $.896^{\mathrm{a}}$ & & & & & & & & & \\
\hline 15. Transaction Time & .002 & .023 & -.189 & -.023 & .082 & -.163 & .079 & .020 & .006 & -.083 & .064 & .062 & -.196 & -.237 & $.906^{\mathrm{a}}$ & & & & & & & & \\
\hline 16. Branch convenience & .021 & -.196 & .028 & .075 & .012 &. .190 & .027 & .137 & .031 & .009 & .026 & .019 & -.139 & -.108 & .052 & $.882^{2}$ & & & & & & & \\
\hline 17. Competitive products & .060 & -.051 & .075 & -.178 & -.104 & .010 & .002 & -.065 & -.107 & .081 & .006 & .079 & -.051 & -.034 & -.122 & -.163 & $.912^{2}$ & & & & & & \\
\hline $\begin{array}{l}\text { 18. Same service level in all } \\
\text { branches }\end{array}$ & -.121 & .087 & .033 & .081 & .022 & .048 & -.038 & .095 & .029 & -.048 & .057 &. .050 & -.002 & .024 & .026 & -.007 &. .224 & $.917^{1}$ & & & & & \\
\hline 19. Bank secrecy & .004 & -.122 & .033 & .031 & .031 &. .107 & -.079 & .004 & .045 & .008 &. .105 & -.185 &. .017 & -.089 & .014 & -.012 & .009 & -.021 & $929^{2}$ & & & & \\
\hline $\begin{array}{l}\text { 20. Trust to bank } \\
\text { management }\end{array}$ &. .128 & .056 & .034 & -.124 & -.049 & .121 & -.054 & -.043 & -.046 & .013 & .059 & .073 & .059 & .047 & -.150 & -.200 & .088 & -.017 & -.315 & $.911^{a}$ & & & \\
\hline 21. Bank size and capital & .002 & .123 & -.111 & -.015 & -.103 & .059 & .014 & .010 & .045 & .002 & .093 & -.112 & -.135 & -.147 & .034 & -.101 & -.114 & .057 & .021 & -.146 & $920^{2}$ & & \\
\hline 22. Low transaction fees & .017 & .060 & -.111 & .122 & .063 & .058 & .000 & .088 & -.012 & .046 & .088 & .002 & .085 & -.051 & .068 & .168 &. .119 & -.133 & .039 &. .152 & -.204 & $.879^{2}$ & \\
\hline 23. Average stable return & .025 & .083 & .011 & -.110 & .067 & .070 & .053 & .037 &. .060 & -.056 & .059 & .040 & .022 & .061 & .074 & .014 &. .185 & -.121 &. .108 & .069 & .036 & -.194 & $.944^{2}$ \\
\hline
\end{tabular}

Appendix 3. Communalities

\begin{tabular}{lrr}
\hline & Initial & Extraction \\
\hline 1.Efficient and fast counter services & 1.000 & .755 \\
2.Speed and efficiency of the transactions & 1.000 & .829 \\
3. Convenience of branches & 1.000 & .253 \\
5.Financial advising & 1.000 & .488 \\
6.Fast document processing & 1.000 & .453 \\
7.Knowledgeable personnell for customer's & 1.000 & .349 \\
requests & & \\
8.Interest free loans & 1.000 & .499 \\
9.Other interest free products and services & 1.000 & .586 \\
10.Compliance to Interest free principles & 1.000 & .649 \\
11.Interest free investment products & 1.000 & .591 \\
12.No interest in transactions & 1.000 & .482 \\
13.Extensive electronic communication & 1.000 & .573 \\
network & & \\
14. Robust international network & 1.000 & .525 \\
15. Time spent for transactions & 1.000 & .488 \\
16. Branch convenience & 1.000 & .514 \\
17. Competitive products & 1.000 & .463
\end{tabular}


18. Same service level in all branches

21. Bank size and capital

22. Low transaction fees

23. Average stable return

$\begin{array}{ll}1.000 & .309 \\ 1.000 & .483 \\ 1.000 & .337 \\ 1.000 & .459\end{array}$

Extraction Method: Principal Component Analysis.

Appendix 4. Scree plot

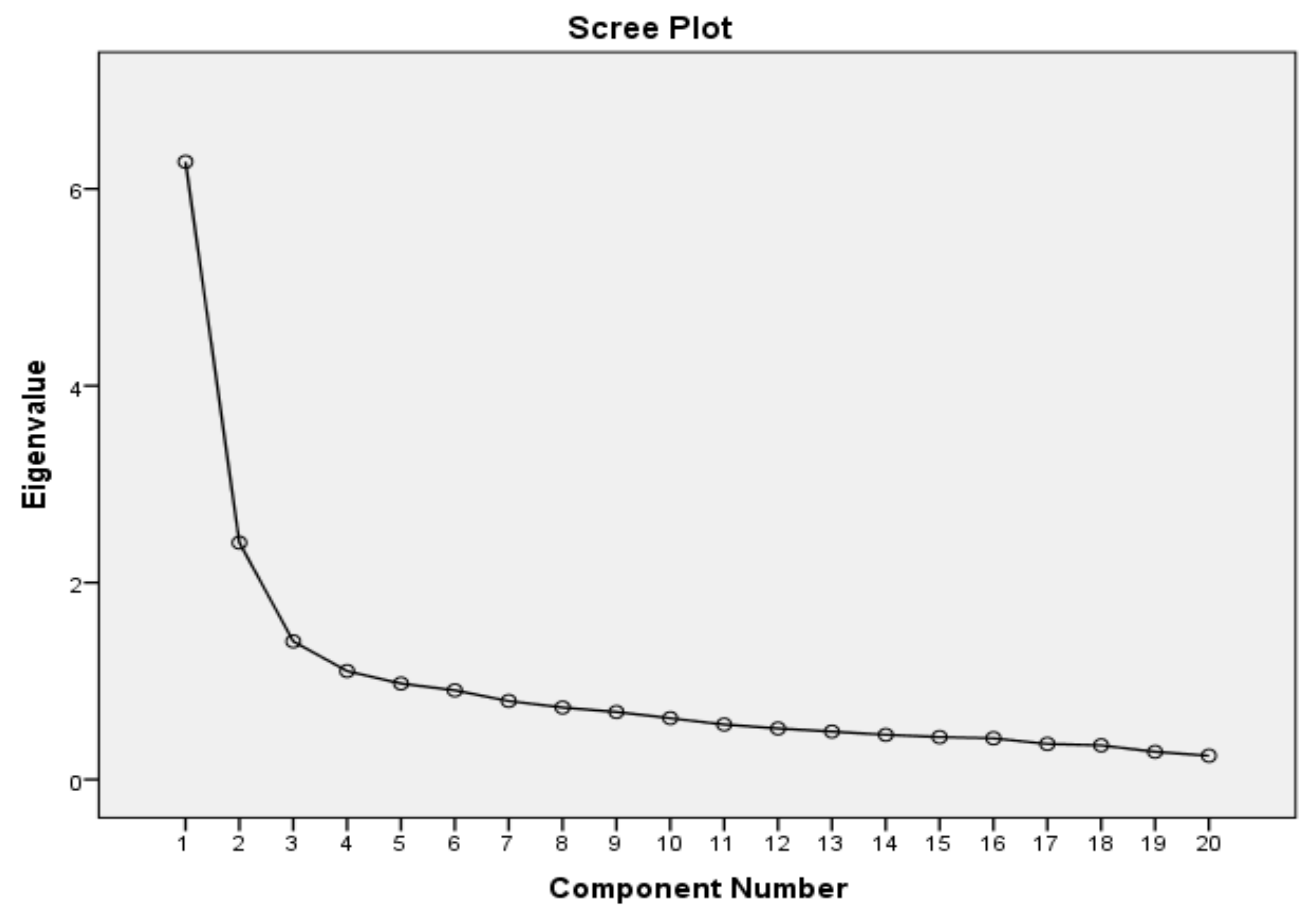

Appendix 5. Mann-Whitney tests

\begin{tabular}{|c|c|c|c|c|}
\hline & & Fast_Banking & $\begin{array}{c}\text { Interest_Free_B } \\
\text { anking }\end{array}$ & $\begin{array}{c}\text { Quality_Bankin } \\
\text { g }\end{array}$ \\
\hline \multirow{4}{*}{$\begin{array}{l}\text { Grouping Variable: } \\
\text { Interest free bank } \\
\text { transactions are more } \\
\text { costly than Conventional } \\
\text { bank transactions? }\end{array}$} & Mann-Whitney U & 13334.500 & 12387.000 & 13250.000 \\
\hline & Wilcoxon W & 36987.500 & 20137.000 & 36903.000 \\
\hline & Z & -.141 & -1.229 & -.233 \\
\hline & $\begin{array}{l}\text { Asymp. Sig. } \\
\text { (2-tailed) }\end{array}$ & .888 & .219 & .815 \\
\hline \multirow{4}{*}{$\begin{array}{l}\text { Grouping Variable: } \\
\text { Would you change your } \\
\text { Participation bank with } \\
\text { another Participation } \\
\text { bank? }\end{array}$} & ney U & 9508.500 & 10601.000 & 9373.500 \\
\hline & Wilcox & 17636.500 & 18729.000 & 17501.500 \\
\hline & & -4.782 & -3.424 & -4.799 \\
\hline & $\begin{array}{l}\text { Asymp. Sig. } \\
\text { (2-tailed) }\end{array}$ & .000 & .001 & .000 \\
\hline \multirow{4}{*}{$\begin{array}{l}\text { Grouping Variable: } \\
\text { Would you prefer } \\
\text { islamic banks even if } \\
\text { they are more costly? }\end{array}$} & & 12578.000 & 14354.500 & 11475.000 \\
\hline & Wilcoxon W & 24206.000 & 25982.500 & 23103.000 \\
\hline & Z & -2.036 & -.011 & -3.199 \\
\hline & $\begin{array}{l}\text { Asymp. Sig. } \\
\text { (2-tailed) }\end{array}$ & .042 & 992 & .001 \\
\hline
\end{tabular}

